\title{
Using Probability for Pathological Complete Response (PCR) as a Decision Support Marker for Neoadjuvant Chemotherapy in HER2 Negative Breast Cancer Patients - a Survey Among Physicians
}

\section{Wahrscheinlichkeit der pathologischen Komplettremission als Entscheidungshilfe für die neoadjuvante Chemotherapie bei HER2- negativen Patientinnen mit Mammakarzinom - eine Umfrage unter Ärzten}

\section{(c) 98}

Authors

Paul Gass ${ }^{1}$, Michael Untch ${ }^{2}$, Volkmar Müller ${ }^{3}$, Volker Möbus ${ }^{4}$, Christoph Thomssen ${ }^{5}$, Lothar Häberle ${ }^{1,6}$, Ramona Erber ${ }^{7}$, Alexander Hein ${ }^{1}$, Sebastian Michael Jud ${ }^{1}$, Michael P. Lux ${ }^{1}$, Carolin C. Hack ${ }^{1}$, Arndt Hartmann ${ }^{7}$, Hans-Christian Kolberg ${ }^{8}$, Johannes Ettl ${ }^{9}$, Diana Lüftner ${ }^{10}$, Christian Jackisch ${ }^{11}$, Matthias W. Beckmann ${ }^{1}$, Wolfgang Janni ${ }^{12}$, Andreas Schneeweiss ${ }^{13,14}$, Peter A. Fasching ${ }^{1}$, Naiba Nabieva ${ }^{1}$

Affiliations

1 Department of Gynecology and Obstetrics, Erlangen University Hospital, Comprehensive Cancer Center ErlangenEMN, Friedrich Alexander University of Erlangen-Nuremberg, Erlangen, Germany

2 Department of Obstetrics and Gynecology, Helios Klinikum Berlin-Buch, Berlin, Germany

3 Hamburg University Hospital, Hamburg, Germany

4 Department of Gynecology and Obstetrics, Klinikum Frankfurt Höchst, Frankfurt, Germany

5 Department of Gynecology, Martin-Luther University Halle-Wittenberg, Halle (Saale), Germany

6 Biostatistics Unit, Department of Gynecology and Obstetrics, Erlangen University Hospital, Comprehensive Cancer Center Erlangen-EMN, Friedrich Alexander University of Erlangen-Nuremberg, Erlangen, Germany

7 Institute of Pathology, Erlangen University Hospital, Comprehensive Cancer Center Erlangen-EMN, Friedrich Alexander University of Erlangen-Nuremberg, Erlangen, Germany

8 Department of Gynecology and Obstetrics, Marienhospital Bottrop, Bottrop, Germany

9 Department of Obstetrics and Gynecology, Klinikum rechts der Isar, Technical University of Munich, Munich, Germany

10 Charité University Hospital, Berlin, Campus Benjamin Franklin, Department of Hematology, Oncology and Tumour Immunology, Berlin, Germany

11 Obstetrics and Gynecology, Klinikum Offenbach GmbH, Offenbach, Germany

12 Department of Gynecology and Obstetrics, University Hospital Ulm, Ulm, Germany
13 National Center for Tumor Diseases, Division Gynecologic Oncology, University Hospital, Heidelberg, Germany

14 Department of Obstetrics and Gynecology, University of Heidelberg, Heidelberg, Germany

Key words breast cancer, pathological complete response (pCR), neoadjuvant, chemotherapy

\section{Schlüsselwörter Brustkrebs, pathologische Komplettremission (PCR), neoadjuvant, Chemotherapie}

$\begin{array}{ll}\text { received } & 10.6 .2018 \\ \text { revised } & 13.6 .2018 \\ \text { accepted } & 14.6 .2018\end{array}$

Bibliography DOI https://doi.org/10.1055/a-0642-9462

Geburtsh Frauenheilk 2018; 78: 707-714 @ Georg Thieme Verlag KG Stuttgart · New York | ISSN 0016-5751

Correspondence

Peter A. Fasching

Department of Gynecology, Erlangen University Hospital, Comprehensive Cancer Center Erlangen, European Metropolitan Area Nuremberg (CCC ER-EMN), Friedrich Alexander University of Erlangen-Nuremberg Universitätsstraße 21-23, 91054 Erlangen, Germany peter.fasching@uk-erlangen.de 


\section{ABSTRACT}

Background In women with early breast cancer, a pathological complete response ( $\mathrm{pCR}$ ) after neoadjuvant chemotherapy is reported to be associated with an improvement of the survival. The aim of this survey among physicians was to investigate whether the probability of achieving $P C R$ in patients with a hormone receptor-positive, HER2-negative disease encourages physicians to recommend neoadjuvant chemotherapy.

Methods The study was conducted via an online survey that was sent to 493 physicians, who were either known as members of national guideline committees, heads of breast cancer centers, being high recruiters in clinical trials or leading a private practice. Participants were asked about a specific case that should resemble patients for whom it is unclear, whether they should be treated with chemotherapy.

Results 113 (24.5\%) physicians participated at the survey, out of which $96.5 \%$ had a work experience of more than 10 years and $94.7 \%$ were board certified in their specialty. A total of $84.1 \%$ would consider PCR for a decision concerning neoadjuvant chemotherapy. With regard to the $\mathrm{PCR}$ probability, 2.7 and $10.6 \%$ of the participants demanded at least a pCR rate of 5 and $10 \%$, respectively, while $25.7 \%$ were satisfied with $20 \%$ probability, and another $25.7 \%$ with a pCR rate of $30 \%$.

Conclusions The vast majority of the long-term experienced physicians would embrace the implementation of a further method such as the prediction of pCR probability in clinical routine to support decision making regarding the necessity of neoadjuvant chemotherapy. The cut-off of around 30\% pCR probability seems to be a realizable rate to distinguish patient groups.

\section{ZUSAMMENFASSUNG}

Hintergrund Die pathologische Komplettremission ( $P C R$ ) nach neoadjuvanter Chemotherapie bei Frauen mit Brustkrebs im Frühstadium weist auf eine verbesserte Überlebenswahrscheinlichkeit hin. Ziel dieser Umfrage unter Ärzten war es, zu untersuchen, ob die Wahrscheinlichkeit, dass eine Komplettremission bei Patientinnen mit hormonrezeptorpositivem/HER2-negativem Brustkrebs erreicht wird, Ärzte ermutigen würde, eine neoadjuvante Chemotherapie zu empfehlen. Methoden Die Studie beruht auf eine Online-Umfrage, die an 493 Ärzte und Ärztinnen geschickt wurde. Alle angeschriebenen Ärzte und Ärztinnen waren entweder Mitglieder nationaler Richtlinien-Kommissionen bzw. Leiter von Brustkrebszentren, hatten bereits viele Patientinnen in klinische Studien rekrutiert oder waren niedergelassene Ärzte bzw. Ärztinnen. Die Teilnehmer wurden nach ihrer Einschätzung eines spezifischen Falles gefragt, wobei der Fall so dargestellt wurde, dass er Ähnlichkeit mit Patientinnen hatte, bei denen die Indikationsstellung für oder gegen Chemotherapie unklar ist.

Ergebnisse Insgesamt nahmen 113 (24,5\%) der angeschriebenen Ärzte an der Umfrage teil. Davon hatten 96,5\% mehr als 10 Jahre Berufserfahrung, und 94,7\% waren Fachärzte. Von den Studienteilnehmern gaben $84,1 \%$ an, dass sie die pathologische Komplettremission bei der Entscheidungsfindung für oder gegen neoadjuvante Chemotherapie heranziehen würden. Was die Wahrscheinlichkeit eines PCR betrifft, gaben 2,7 bzw. 10,6\% der Teilnehmer an, dass sie eine PCR-Rate von mindestens 5 bzw. 10\% erwarteten, wohingegen 25,7\% mit einer 20\%iger Wahrscheinlichkeit und weitere 25,7\% mit einer pCR-Rate von $30 \%$ zufrieden wären.

Schlussfolgerungen Die überwiegende Mehrzahl der Ärzte mit langjähriger Erfahrung würden die Einführung einer weiteren Methode als Unterstützungshilfe bei der Entscheidungsfindung, beispielsweise die Voraussage der pCR-Wahrscheinlichkeit, in der klinischen Praxis begrüßen. Ein Schwellenwert von rund $30 \%$ für die Wahrscheinlichkeit eines PCR scheint ein geeigneter Wert zu sein, um eine Unterscheidung zwischen verschiedenen Patientinnengruppen vorzunehmen.

\section{Introduction}

In women with early breast cancer (BC), a pathological complete response ( $p C R$ ) after neoadjuvant chemotherapy is reported to be associated with improvements in the disease-free survival (DFS) and overall survival (OS) $[1,2]$. This is the main reason why PCR is currently being discussed as a surrogate marker for the effectiveness of chemotherapy [3-5]. However, therapy response and outcomes for patients differ depending on the tumor biology. HER2positive and triple-negative $B C$ patients not only achieve $p C R$ more frequently than those with luminal disease, but also have the strongest association with a better prognosis when no residual cancer is found at surgery $[1,2,6]$. This in turn means that in women with hormone receptor-positive, HER2-negative disease, identifying those patients who are more likely to benefit from chemotherapy is an unresolved issue.
In order to make a decision for or against chemotherapy in this patient population, a mixture of prognostic and predictive factors has usually been taken into consideration, with the likelihood of a treatment response being weighed up against the prognosis for the individual patient. Tumor size, lymph-node status, tumor grade, estrogen receptor (ER) status, progesterone receptor (PR) status, and in some institutions Ki-67 and UPA/PAI- 1 status are the main factors in clinical routine work that are used to assess the need for chemotherapy [7-10]. Multigene assays are also being incorporated into clinical routine work to estimate the patients' prognosis and spare patients who have an excellent prognosis the need to undergo chemotherapy [11-13]. This approach was recently confirmed by the TailorX study [14]. Patients were eligible for randomization within the trial (chemotherapy and endocrine treatment vs. endocrine treatment alone) if they had a hormone receptor-positive and HER2-negative breast cancer and an 
intermediate recurrence risk as assessed by a 21-multigene assay (for this study defined as 11-25). The tumors also had to be nodenegative. The study showed that endocrine therapy alone is as effective as chemotherapy and endocrine treatment. For women under the age of 50 , however, a potential additional benefit from chemotherapy could not be excluded [14].

However, it is still not clear from this trial which individual patients will benefit from chemotherapy. In addition, patients who had a recurrence score over 25 did not undergo randomization in the TailorX study but were assigned to receive endocrine therapy and chemotherapy. This group of patients had the poorest prognosis in the study [14], and it is unclear whether this group benefits from chemotherapy at all.

A new biomarker indicating the probability of $\mathrm{PCR}$ in patients with hormone receptor-positive HER2-negative breast cancer could potentially be helpful in identifying a patient population in which the patients and physicians would feel comfortable with an indication for neoadjuvant chemotherapy. The aims of the present survey carried out among physicians were therefore to investigate whether the probability of achieving PCR in hormone receptor-positive, HER2-negative BC patients may encourage physicians to recommend neoadjuvant chemotherapy; and to establish a cut-off level for a pCR rate that most physicians would consider high enough to serve as an indication for the treatment.

\section{Methods}

\section{Data acquisition}

An anonymized online survey was conducted using SurveyMonkey (San Mateo, California, USA) in German. The study was conducted in Germany in May 2018 and included physicians who were known as members of national guideline committees, heads of breast cancer centers, frequent recruiters in clinical trials, or running private practices. The e-mail addresses for the survey were obtained by Internet research or were known from the authors' personal communications.

The link to the survey was sent to a total of 493 medical professionals by e-mail and was open for 8 days (May 17 to May 24, 2018). The recipients were reminded to participate in the survey three times (on May 18, 23, and 24, 2018). The data were completely anonymized before the analysis and no personal data were permanently stored.

The survey comprised 13 questions and one comment field. Seven items captured the participants' characteristics $(\triangleright$ Table 1) and six items collected data about which tumor and patient characteristics might guide the physician with regard to making a decision for or against chemotherapy. This was done by asking about a specific case intended to resemble a patient for whom it is unclear whether she should be treated with chemotherapy: a 60 -year-old patient (with no further comorbidities) with an invasive ductal carcinoma $2.5 \mathrm{~cm}$ in diameter, G2, one positive lymph node, estrogen receptor-positive, progesterone receptor-positive, HER2-negative ( $\triangleright$ Table 2 ).
- Table 1 Characteristics of participants.

\begin{tabular}{|c|c|c|}
\hline Question & $\mathbf{n}$ & $\begin{array}{l}\text { Mean } \\
\text { (SD) or \% }\end{array}$ \\
\hline How old are you (in years)? & 113 & $\begin{array}{l}50.5 \\
(8.04)\end{array}$ \\
\hline \multicolumn{3}{|c|}{$\begin{array}{l}\text { Are you a decision-maker on the oncologic } \\
\text { treatment of breast cancer patients? }\end{array}$} \\
\hline - Yes & 107 & 94.7 \\
\hline - No & 6 & 5.3 \\
\hline - Total & 113 & 100.0 \\
\hline \multicolumn{3}{|l|}{ Where do you work? } \\
\hline - Hospital & 82 & 72.6 \\
\hline - Practice & 27 & 23.9 \\
\hline - Other & 4 & 3.5 \\
\hline - Total & 113 & 100.0 \\
\hline \multicolumn{3}{|c|}{$\begin{array}{l}\text { Are you a member of a guideline group ( } \mathrm{S} 3 \text {, } \\
\mathrm{AGO}, \mathrm{ABC}, \mathrm{NCCN} \text {, etc.)? }\end{array}$} \\
\hline - Yes & 40 & 35.4 \\
\hline - No & 73 & 64.6 \\
\hline - Total & 113 & 100.0 \\
\hline \multicolumn{3}{|c|}{ What is your specialist discipline? } \\
\hline - Gynecology & 95 & 84.1 \\
\hline - Oncology & 16 & 14.2 \\
\hline - Not working as a physician & 1 & 0.9 \\
\hline - Other & 1 & 0.9 \\
\hline - Total & 113 & 100.0 \\
\hline \multicolumn{3}{|l|}{ Are you a medical specialist? } \\
\hline - Yes & 107 & 94.7 \\
\hline - No & 6 & 5.3 \\
\hline - Total & 113 & 100.0 \\
\hline \multicolumn{3}{|c|}{$\begin{array}{l}\text { How many years of work experience do you } \\
\text { have? }\end{array}$} \\
\hline - Less than 10 years & 4 & 3.5 \\
\hline - Between 10 and 20 years & 35 & 31.0 \\
\hline - More than 20 years & 74 & 65.5 \\
\hline . Total & 113 & 100.0 \\
\hline
\end{tabular}

\section{Statistical methods}

The responses were evaluated descriptively by using means and standard deviation or percentage and number of participants. Analyses were performed with IBM SPSS Statistics for Windows, Version 21.0 (IBM Corporation, Armonk, New York, USA).

\section{Results}

\section{Participants}

E-mail delivery failed in a total of 32 cases (6.5\%), so that the final group consisted of 461 recipients, of whom 113 (24.5\%) responded to the survey ( $\triangleright$ Fig. 1 ). 


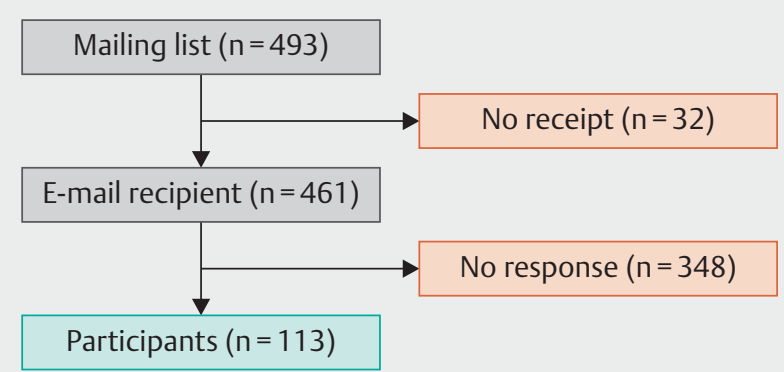

- Fig. 1 Participant flow chart.

The participants had an average age of 50.5 years (standard deviation 8.0) and had work experience of more than 10 years in $96.5 \%$ of cases. Their workplaces were a hospital setting in $72.6 \%$ of cases ( $n=82)$ and in a practice setting in $23.9 \%(n=27)$. Most participants were gynecologists $(84.1 \% ; n=95)$ and $14.2 \%$ $(n=16)$ were oncologists. A total of 107 participants (94.7\%) stated that they were board-certified in their specialty and the same number confirmed that they were responsible for making treatment decisions at their institution. Finally, 40 participants (35.4\%) were members of a national or international guideline committee. The participants' characteristics are summarized in - Table 1.

\section{Chemotherapy decision criteria}

For the case described in the Methods section for each of the parameters ER, PR, and Ki-67, it was asked whether the magnitude of the expression in percentage assessed by immunohistochemistry $(0-100 \%)$ had an influence on decision-making for or against neoadjuvant chemotherapy. The respondents stated that the magnitude of ER and PR expression would influence that decision in the specific case in $57.5 \%(n=65)$ and $46.0 \%(n=52)$ of cases, respectively. Ki-67 expression would have an influence on chemotherapy decision-making for $102(90.3 \%)$ of the participants ( $\bullet$ Table 2 and Fig. 2 ).

In relation to the probability of $\mathrm{pCR}$, a total of 95 participants $(84.1 \%)$ stated that they would take this measure into account in decision-making concerning neoadjuvant chemotherapy. With regard to the probability of pCR, $2.7 \%(n=3)$ and $10.6 \%(n=12)$ of the participants would require $P C R$ rates of at least 5 and $10 \%$, respectively, while $25.7 \%(n=29)$ would be satisfied with a probability of $20 \%$ and a further $25.7 \%(n=29)$ would be satisfied with a PCR rate of $30 \%$. Thus, $64.7 \%$ would be satisfied with a pCR rate of $30 \%$ ( $\triangleright$ Table 2 and Fig. 2 ).

In total, $24.8 \%$ of respondents were able to imagine that information about the probability of $\mathrm{pCR}$ would be capable of influencing chemotherapy decision-making when combined with a multigene assay. In contrast, in the opinion of $47.8 \%$ this might be the case even independently of a multigene assay ( $\bullet$ Table 2 and Fig. 2).
- Table 2 Survey results on decision-making criteria for chemotherapy.

\begin{tabular}{l|c|c|}
\hline $\begin{array}{l}\text { Question } \\
\text { In a 60-year-old patient (with no further comorbidities) }\end{array}$ & with an inva- \\
$\begin{array}{l}\text { sive ductal carcinoma 2.5 cm in diameter, G2, one positive lymph node, } \\
\text { ER-positive, PR-positive, HER2-negative: }\end{array}$ \\
\hline $\begin{array}{l}\text { Does your decision regarding chemotherapy depend on the expression } \\
\text { of ER (in \%)? }\end{array}$ \\
\hline - No & 48 & 42.5 \\
\hline - Yes & 65 & 57.5 \\
\hline - Total & 113 & 100.0 \\
\hline $\begin{array}{l}\text { Does your decision regarding chemotherapy depend on the expression } \\
\text { of PR (in \%)? }\end{array}$ & 61 \\
\hline - No & 52 & 46.0 \\
\hline - Yes & 113 & 100.0 \\
\hline - Total
\end{tabular}

Does your decision regarding chemotherapy depend on the expression of Ki-67 (in \%)?

\begin{tabular}{|l|r|r|}
\hline - No & 11 & 9.7 \\
\hline " Yes & 102 & 90.3 \\
\hline - Total & 113 & 100.0 \\
\hline
\end{tabular}

If you knew how high the probability of achieving a pCR through neoadjuvant chemotherapy is, would you use this information to make a decision for or against neoadjuvant chemotherapy?

\begin{tabular}{|l|r|r|}
\hline - No & 18 & 15.9 \\
\hline - Yes & 95 & 84.1 \\
\hline - Total & 113 & 100.0 \\
\hline
\end{tabular}

How high should the probability of achieving $\mathrm{pCR}$ be in order to perform neoadjuvant chemotherapy (e.g., four cycles of epirubicin/cyclophosphamide followed by 12 cycles of paclitaxel)?

\begin{tabular}{|l|r|r|}
\hline - At least $5 \%$ & 3 & 2.7 \\
\hline - At least 10\% & 12 & 10.6 \\
\hline - At least 20\% & 29 & 25.7 \\
\hline - At least 30\% & 29 & 25.7 \\
\hline - At least $40 \%$ & 21 & 18.6 \\
\hline - At least $50 \%$ & 19 & 16.8 \\
\hline - Total & 113 & 100.0 \\
\hline
\end{tabular}

Can you imagine that information about the probability of pCR could influence treatment decision-making, as with a multigene assay?

\begin{tabular}{|l|r|r|}
\hline \begin{tabular}{l} 
- No \\
\hline $\begin{array}{l}\text { Yes, in combination with a multigene } \\
\text { assay }\end{array}$
\end{tabular} & \multicolumn{1}{|c|}{4} & 3.5 \\
\hline $\begin{array}{l}\text { - Yes, even independently of a multigene } \\
\text { assay }\end{array}$ & 54 & 47.8 \\
\hline & & \\
\hline - Possibly, not yet certain & 27 & 23.9 \\
\hline - Total & 113 & 100.0 \\
\hline
\end{tabular}

ER: estrogen receptor; $\mathrm{pCR}$ : pathological complete response; PR: progesterone receptor 
a Does your decision regarding chemotherapy depend on the expression of ER/PR/Ki-67 (in \%)?

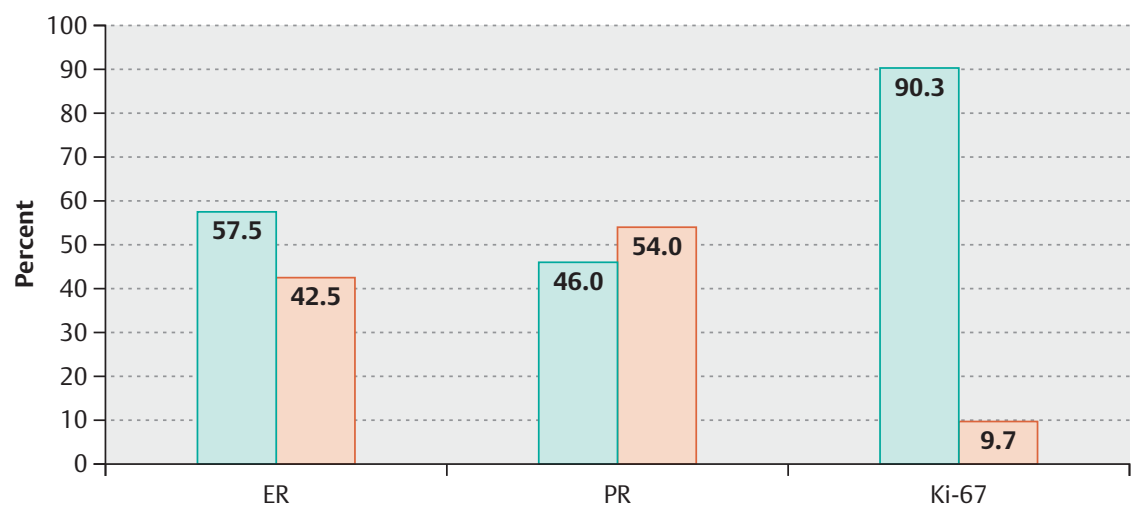

b If you knew how high the probability of achieving $\mathrm{PCR}$ under neoadjuvant chemotherapy is, would you use this information to make a decision for or against neoadjuvant chemotherapy?

c How high should the probability of achieving PCR be to perform neoadjuvant chemotherapy (e.g. 4 cycles of epirubicin/ cyclophosphamide, followed by 12 cycles of paclitaxel)?

d Can you imagine that the knowledge about $\mathrm{pCR}$ probability may influence therapy decision making like a multigene assay?
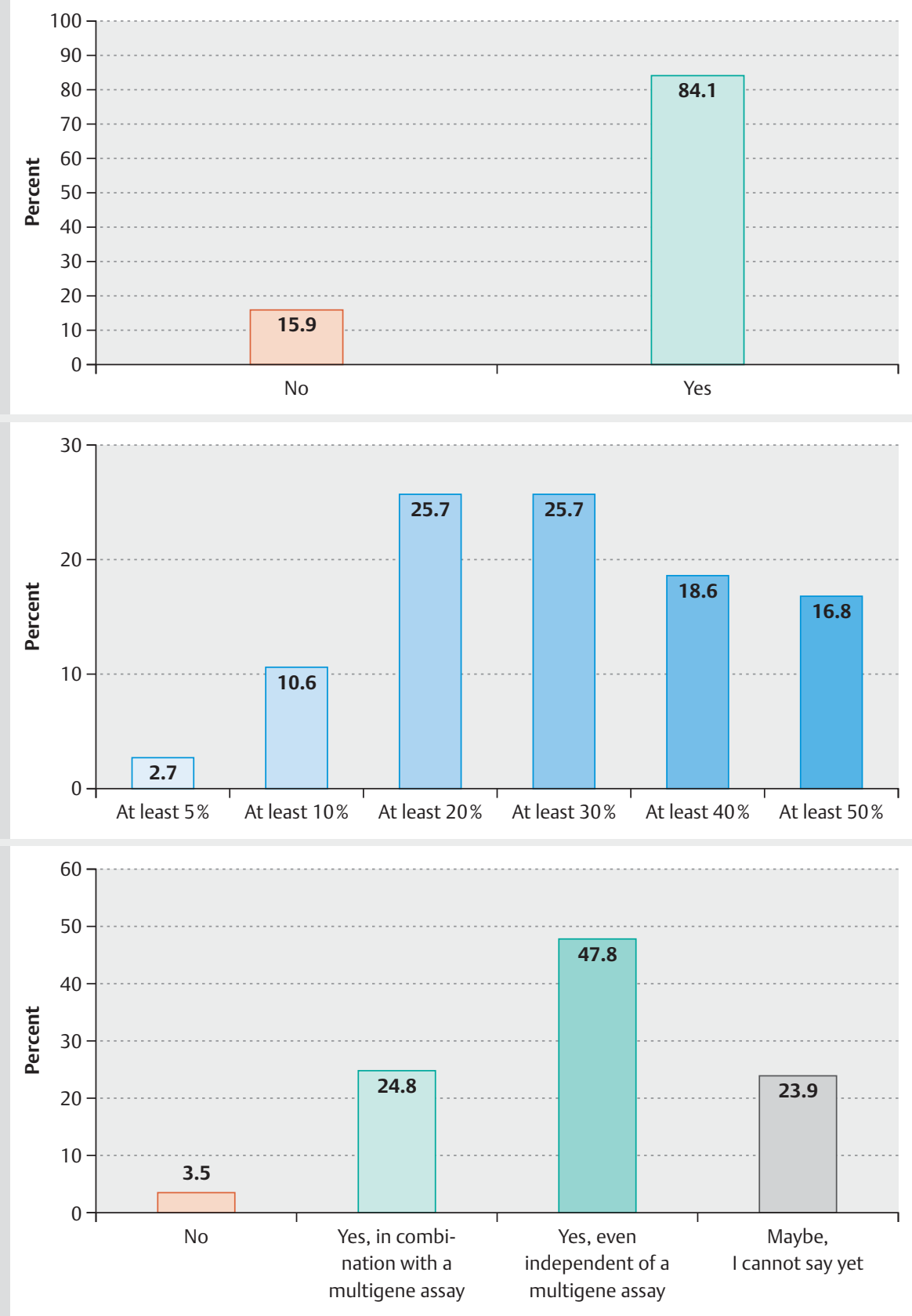

- Fig. 2 Survey results on chemotherapy decision criteria. 


\section{Discussion}

The online survey conducted shows that the majority of physicians are able to imagine using the probability of $\mathrm{pCR}$ as a marker in decision-making for or against chemotherapy. It also shows that approximately two thirds of the participating physicians would be satisfied with a pCR probability of $30 \%$ or lower, meaning that the physicians would accept treating seven out of $10 \mathrm{pa}-$ tients with chemotherapy without achieving a pCR.

The survey inquired about a patient with hormone receptorpositive, HER2-negative BC - a group of patients in whom the correlation between $\mathrm{pCR}$ and prognosis is not as well established as in triple-negative or HER2-positive BC patients [1,2]. There are also only limited data regarding the extent to which the quantitative expression of ER, PR, and Ki-67 influences PCR rates. ER, PR, and Ki-67 are usually assessed with immunohistochemistry, and expression is reported in a quantitative fashion; however, when it comes to correlation with $\mathrm{pCR}$, these markers are used as dichotomous variables (positive/negative). Hormone receptor-positive patients are reported to have fairly low $\mathrm{pCR}$ rates, while hormone receptor-negative patients have fairly high $p C R$ rates $[1,2,6,15-$ 17]. In addition - specifically in luminal-like tumors - there are several reports that have correlated increasing Ki-67 expression with increasing $p C R$ rates $[6,18,19]$.

In clinical practice, cut-off levels are used to categorize breast cancer patients into positive versus negative. ER and PR were initially categorized to distinguish between women who benefit from endocrine therapy from those who do not, and the levels have varied from $10 \%$ through $1-10 \%$ to $\geq 1 \%$ over the years [20-22]. These cut-off levels were therefore also used to learn about the correlation with chemotherapy responsiveness [23].

The present survey shows that most physicians would be satisfied with a $30 \%$ rate of PCR. To meet that criterion, it is not known which cut-off levels for ER, PR, and Ki-67 should be used. Including these markers additionally to conventional patient and tumor characteristics might be helpful for exploring this topic further.

Other studies have also examined decision-making parameters for neoadjuvant chemotherapy in hormone receptor-positive patients. A large prospective noninterventional study in postmenopausal women showed that age, body mass index, tumor grade, HER2 status, and the fact that patients were taking concomitant medication were influencing factors in relation to decision-making for or against neoadjuvant chemotherapy [24]. Information about the patient's pCR status could further add to this list of influencing factors.

Independently of the prediction of $\mathrm{pCR}$, the question remains of how to estimate the effect of chemotherapy and/or pCR on the prognosis. While an association between $\mathrm{PCR}$ and prognosis has been well described, some studies have shown that there may be subgroups of patients who do not benefit as much from chemotherapy as others, even among those with triple-negative findings $[1,25]$. Two studies have described such an effect for BRCA mutation carriers [26, 27]. However, it must be noted that other studies have not observed this effect $[28,29]$. On the other hand, there is evidence from the GeparSepto study that a benefit of chemotherapy vs. another treatment may be conferred even in a subgroup in which the chemotherapy comparison does not show a difference in pCR rates [30]. Additionally it is even hypothesized that in some subgroups such as lobular breast cancer chemotherapy might be even harmful [31]. There are several predictive methods that assess the prognosis either using clinical variables or multigene assays, or both together [14,32-36]. However, these predictors have not included pCR or the effects of neoadjuvant chemotherapy in the models.

One strength of the present survey is not only that approximately $25 \%$ of the recipients participated in the survey, but also that some $95 \%$ of them were board-certified. The results thus represent the views of physicians with substantial experience. A large number of guideline committee members also appear to have taken part in the survey. The study is of course only a survey among physicians and does not reflect the actual behavior of physicians using the probability of $\mathrm{pCR}$ as a decision-making criterion. However, such a marker is not available at the moment, so that considerations at present can be only hypothetical. It should be noted that physicians were only asked about their opinion of which $\mathrm{PCR}$ rate they would require for a decision in favor of neoadjuvant therapy, and no patients were included in the survey. However, it is known that the size of the treatment effect required may differ widely between physicians and patients when they are asked about a case and about possible treatment effects $[37,38]$.

\section{Conclusion}

This survey shows that $84 \%$ of physicians with long-term experience would welcome the possibility of using the probability of PCR in decision-making concerning neoadjuvant chemotherapy in a patient with hormone receptor-positive, HER2-negative breast cancer. The majority of the respondents appeared to be satisfied with a cut-off level of a pCR probability around $30 \%$. However, further research will be needed in order to establish this type of $\mathrm{pCR}$ probability marker and the way in which it could be used in clinical practice.

\section{Acknowledgements}

We are grateful to all of the participants for supporting this survey. The authors are grateful to Michael Robertson for professional medical editing services.

\section{Conflict of Interest}

P. G. has received honoraria from Novartis, financial support for symposia from Novartis, Roche, and PharmaMar, and compensation for travel expenses from discovering hands ${ }^{\circledR}$. V. M. has received speaker honoraria from Amgen, AstraZeneca, Celgene, Daiichi Sankyo, Eisai, Pfizer, Pierre-Fabre, Novartis, Roche, Teva, and Janssen-Cilag and consultancy honoraria from Genomic Health, Roche, Pierre Fabre, Amgen, Daiichi Sankyo, and Eisai. V. Mö. has received honoraria from Amgen, Celgene, Roche and participation in advisory boards (Celgene und Myelotherapeutics). C. T. compensated honoraria for presentations and participation in advisory boards (Amgen, Astra-Zeneca, Celgene, Daiichi Sankyo, Genomic-Health, Lilly, Mundipharma, Nanostring, Novartis, Pfizer, Puma, Roche). R. E. has received speaker honoraria from Roche and Eisai. M.P. L. has participated on advisory boards for AstraZeneca, MSD, Novartis, Pfizer, Genomic Health, and Roche and has received honoraria for lectures from Lilly, Roche, Novartis, Pfizer, Genomic Health, Astra- 
Zeneca, medac, and Eisai. H.-C. K. has received honoraria from Carl Zeiss meditec, TEVA, Theraclion, Novartis, Amgen, Astra Zeneca, Pfizer, Janssen-Cilag, GSK, LIV Pharma, Roche, and Genomic Health. J. E. has participated on advisory boards for Novartis, Pfizer, Roche, TEVA, Lilly, Eisai and has received honoraria for lectures and/or travel support from Lilly, Roche, Novartis, Pfizer. P. A. F. has received honoraria from Roche, Pfizer, Novartis, and Celgene. N. N. has received consultancy honoraria from Janssen-Cilag and travel support from Novartis.

All of the remaining authors have declared that they have no conflicts of interest.

\section{References}

[1] Cortazar P, Zhang L, Untch M et al. Pathological complete response and long-term clinical benefit in breast cancer: the CTNeoBC pooled analysis. Lancet 2014; 384: 164-172

[2] von Minckwitz G, Untch M, Blohmer JU et al. Definition and impact of pathologic complete response on prognosis after neoadjuvant chemotherapy in various intrinsic breast cancer subtypes. J Clin Oncol 2012; 30: 1796-1804

[3] US Department of Health and Human Services; Food and Drug Administration Center for Drug Evaluation and Research. Guidance for Industry Pathological Complete Response in Neoadjuvant Treatment of High-Risk Early-Stage Breast Cancer: Use as an Endpoint to Support Accelerated Approval. 2014. Online: https://wwwfdagov/downloads/drugs/guidances /ucm305501pdf 2014; last access: 28.02.2018

[4] Cortazar P, Geyer CE jr. Pathological complete response in neoadjuvant treatment of breast cancer. Ann Surg Oncol 2015; 22: 1441-1446

[5] European Medicines Agency. The role of the pathological Complete Response as an endpoint in neoadjuvant breast cancer studies (2014). Online: http://wwwemaeuropaeu/docs/en_GB/document_library/ Scientific_guideline/2014/04/WC500165781pdf; last access: 28.02.2018

[6] Fasching PA, Heusinger K, Haeberle L et al. Ki67, chemotherapy response, and prognosis in breast cancer patients receiving neoadjuvant treatment. BMC Cancer 2011; 11: 486

[7] Taran FA, Schneeweiss A, Lux MP et al. Update Breast Cancer 2018 (Part 1) - Primary Breast Cancer and Biomarkers. Geburtsh Frauenheilk 2018; 78: $237-245$

[8] Lux MP, Janni W, Hartkopf AD et al. Update Breast Cancer 2017 - Implementation of Novel Therapies. Geburtsh Frauenheilk 2017; 77: 12811290

[9] Untch M, Huober J, Jackisch C et al. Initial Treatment of Patients with Primary Breast Cancer: Evidence, Controversies, Consensus: Spectrum of Opinion of German Specialists at the 15th International St. Gallen Breast Cancer Conference (Vienna 2017). Geburtsh Frauenheilk 2017; 77: 633644

[10] Schmidt M, Fasching PA, Beckmann MW et al. Biomarkers in Breast Cancer - An Update. Geburtsh Frauenheilk 2012; 72: 819-832

[11] Sestak I, Buus R, Cuzick J et al. Comparison of the Performance of 6 Prognostic Signatures for Estrogen Receptor-Positive Breast Cancer: A Secondary Analysis of a Randomized Clinical Trial. JAMA Oncol 2018; 4: 545-553

[12] Cardoso F, van't Veer LJ, Bogaerts J et al. 70-Gene Signature as an Aid to Treatment Decisions in Early-Stage Breast Cancer. N Engl J Med 2016; 375: 717-729

[13] Sparano JA, Gray RJ, Makower DF et al. Prospective Validation of a 21 Gene Expression Assay in Breast Cancer. N Engl J Med 2015; 373: $2005-$ 2014

[14] Sparano JA, Gray RJ, Makower DF et al. Adjuvant Chemotherapy Guided by a 21-Gene Expression Assay in Breast Cancer. N Engl J Med 2018. doi:10.1056/NEJMoa 1804710
[15] Untch M, Fasching PA, Konecny GE et al. Pathologic complete response after neoadjuvant chemotherapy plus trastuzumab predicts favorable survival in human epidermal growth factor receptor 2-overexpressing breast cancer: results from the TECHNO trial of the AGO and GBG study groups. J Clin Oncol 2011; 29: 3351-3357

[16] Huober J, von Minckwitz G, Denkert C et al. Effect of neoadjuvant anthracycline-taxane-based chemotherapy in different biological breast cancer phenotypes: overall results from the GeparTrio study. Breast Cancer Res Treat 2010; 124: 133-140

[17] von Minckwitz G, Blohmer JU, Raab G et al. In vivo chemosensitivityadapted preoperative chemotherapy in patients with early-stage breast cancer: the GEPARTRIO pilot study. Ann Oncol 2005; 16: 56-63

[18] Lips EH, Mulder L, de Ronde J] et al. Breast cancer subtyping by immunohistochemistry and histological grade outperforms breast cancer intrinsic subtypes in predicting neoadjuvant chemotherapy response. Breast Cancer Res Treat 2013; 140: 63-71

[19] Kim KI, Lee KH, Kim TR et al. Ki-67 as a predictor of response to neoadjuvant chemotherapy in breast cancer patients. J Breast Cancer 2014; 17: $40-46$

[20] Goldhirsch A, Wood WC, Gelber RD et al. Meeting highlights: updated international expert consensus on the primary therapy of early breast cancer. J Clin Oncol 2003; 21: 3357-3365

[21] Goldhirsch A, Glick JH, Gelber RD et al. Meeting highlights: international expert consensus on the primary therapy of early breast cancer 2005 . Ann Oncol 2005; 16: 1569-1583

[22] Hammond ME, Hayes DF, Wolff AC. Clinical Notice for American Society of Clinical Oncology-College of American Pathologists guideline recommendations on ER/PgR and HER2 testing in breast cancer. J Clin Oncol 2011; 29: e458

[23] Goldhirsch A, Ingle JN, Gelber RD et al. Thresholds for therapies: highlights of the St Gallen International Expert Consensus on the primary therapy of early breast cancer 2009. Ann Oncol 2009; 20: 1319-1329

[24] Gass P, Fasching PA, Fehm T et al. Factors Influencing Decision-Making for or against Adjuvant and Neoadjuvant Chemotherapy in Postmenopausal Hormone Receptor-Positive Breast Cancer Patients in the EvAluate-TM Study. Breast Care (Basel) 2016; 11: 315-322

[25] Early Breast Cancer Trialists' Collaborative Group (EBCTCG). Long-term outcomes for neoadjuvant versus adjuvant chemotherapy in early breast cancer: meta-analysis of individual patient data from ten randomised trials. Lancet Oncol 2018; 19: 27-39

[26] Paluch-Shimon S, Friedman E, Berger R et al. Neo-adjuvant doxorubicin and cyclophosphamide followed by paclitaxel in triple-negative breast cancer among BRCA1 mutation carriers and non-carriers. Breast Cancer Res Treat 2016; 157: 157-165

[27] Fasching PA, Loibl S, Hu C et al. BRCA1/2 Mutations and Bevacizumab in the Neoadjuvant Treatment of Breast Cancer: Response and Prognosis Results in Patients With Triple-Negative Breast Cancer From the GeparQuinto Study. J Clin Oncol 2018. doi:10.1200/JCO.2017.77.2285

[28] Wunderle M, Gass P, Haberle L et al. BRCA mutations and their influence on pathological complete response and prognosis in a clinical cohort of neoadjuvantly treated breast cancer patients. Breast Cancer Res Treat 2018. doi:10.1007/s10549-018-4797-8

[29] Hahnen E, Lederer B, Hauke J et al. Germline Mutation Status, Pathological Complete Response, and Disease-Free Survival in Triple-Negative Breast Cancer: Secondary Analysis of the GeparSixto Randomized Clinical Trial. JAMA Oncol 2017; 3: 1378-1385

[30] Schneeweiss A, Jackisch C, Schmatloch S et al. Survival analysis of the prospectively randomized phase III GeparSepto trial comparing neoadjuvant chemotherapy with weekly nab-paclitaxel with solvent-based paclitaxel followed by anthracycline/cyclophosphamide for patients with early breast cancer-GBG69. Cancer Research 2018. doi:10.1158/15387445.SABCS17-GS3-05 
[31] Tamirisa NP, Vernia H, Thomas SM et al. The impact of chemotherapy sequence on survival in node-positive invasive lobular carcinoma. J Clin Oncol 2018; 36 (Suppl.): Abstr. 587

[32] Buus R, Sestak I, Kronenwett R et al. Comparison of EndoPredict and EPclin With Oncotype DX Recurrence Score for Prediction of Risk of Distant Recurrence After Endocrine Therapy. J Natl Cancer Inst 2016. doi:10.1093/jnci/djw149

[33] Cuzick J, Dowsett M, Pineda S et al. Prognostic value of a combined estrogen receptor, progesterone receptor, Ki-67, and human epidermal growth factor receptor 2 immunohistochemical score and comparison with the Genomic Health recurrence score in early breast cancer. J Clin Oncol 2011; 29: 4273-4278

[34] Dowsett M, Sestak I, Lopez-Knowles E et al. Comparison of PAM50 risk of recurrence score with oncotype DX and IHC4 for predicting risk of distant recurrence after endocrine therapy. J Clin Oncol 2013; 31: 27832790
[35] Ravdin PM, Siminoff LA, Davis G] et al. Computer program to assist in making decisions about adjuvant therapy for women with early breast cancer. J Clin Oncol 2001; 19: 980-991

[36] Wishart GC, Bajdik CD, Dicks E et al. PREDICT Plus: development and validation of a prognostic model for early breast cancer that includes HER2. Br J Cancer 2012; 107: 800-807

[37] Thiel FC, Schrauder MG, Fasching PA et al. Shared decision-making in breast cancer: discrepancy between the treatment efficacy required by patients and by physicians. Breast Cancer Res Treat 2012; 135: 811-820

[38] Lux MP, Bayer CM, Loehberg CR et al. Shared decision-making in metastatic breast cancer: discrepancy between the expected prolongation of life and treatment efficacy between patients and physicians, and influencing factors. Breast Cancer Res Treat 2013; 139: 429-440 